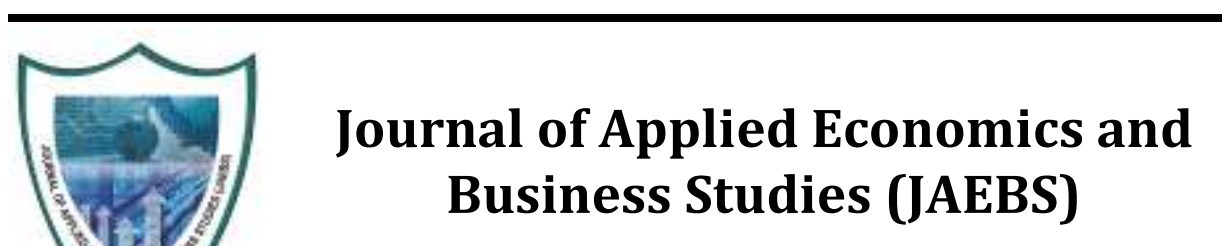

Journal homepage: https://jaebs.com

ISSN (Print): 2523-2614

ISSN (Online): 2663-693X

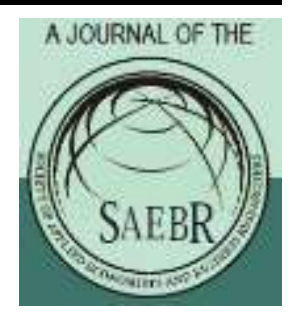

\title{
The impact of military spending on economic growth of Pakistan
}

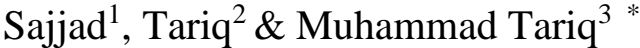 \\ ${ }^{1}$ Assistant Professor of Economics at Higher Education Department, Khyber Pakhtunkhwa. \\ ${ }^{2} \mathrm{PhD}$ Scholar, Department of Economics, Abdul Wali Khan University, Mardan. \\ ${ }^{3}$ Assistant Professor, Department of Economics, Abdul Wali Khan University, Mardan
}

\begin{abstract}
A sound national defence is extremely essential for a country's sovereignty. The geostrategic position of Pakistan and its deterrence policy against neighbouring India have generally been the reasons for stringent military financing. Defence spending affects all sectors of the economy directly or indirectly. This study aims to investigate the influence of government military expenditures on the economic growth of Pakistan over the period 1987-2016. Augmented Dickey-Fuller test has been used for checking the unit root in the data. Autoregressive Distributed Lag (ARDL) bounds testing approach to cointegration has been applied to analyze the relationship between military spending and economic growth. The findings indicate that military expenditure has a positive impact on Pakistan's economic growth in the long-run, however it has negative effect on economic growth in the short-run.
\end{abstract}

Keywords

Military spending, Economic growth, ARDL, Pakistan JEL Classification H 55

\section{Introduction}

A sound national defence is extremely essential for a country's sovereignty. All countries around the world defend their boundaries and control internal riots by keeping forces such as navy, air force, and the army. All citizens get benefits from the defence services of forces. Likewise, these citizens also bear the entire expenses of the troops which are called military expenditures. Most studies have shown that military spending is positively linked to the economic growth of less developed countries (Augier et al., 2015). Benoit (1973) used cross-sectional data for 44 less-developed countries and found a positive and significant association between military spending and economic growth. 
The proponents of Keynesian economics argue that when aggregate demand is insufficient in relation to potential supply, the increase demand for military spending positively affects labour, employment, and capital stock. So efficient utilization leads to higher profit, which stimulates investment and as result growth rate increases (Khilji and Mahmood, 1997; Benoit, 1973; and Fiani et al, 1984). Secondly, there is an opportunity cost of military expenditures and could also have implications for balance of payments (BOP). Thirdly, positive effect of military spending on growth is also anticipated in the sense that in many developing countries like Pakistan military forces are engaged in the developmental projects such as constructions of schools, roads, and hospitals. They are also engaged in the provision of health care, educational facilities, and other technical trainings not only to military but also to general public.

The nature of military or defence expenditures varies from region to region and country to country. The most common indicators to measure the military expenditures are the number of armed forces, the percentage of military expenditure of the country's total gross domestic product, and expenditure per military person. The Stockholm International Peace Research Institute reported recently that about 1686 billion US dollars were spent on global defence expenditure in 2016, more than 0.4 percent of real defence spending in 2015. The report also shows that most countries of the world are continually increasing their defence expenditures. Similarly, most of the Asian countries also increased their military spending. In terms of military expenditures, the countries of Asia and Oceania were the second largest regions during 2017. Moreover, the governments of U.S, China, Saudi Arabia, and Russia are spending more on their defences as compared to other nations of the world. India has also increased their military expenditure during the last decades. Indian authorities have extended their spending on military by $5.5 \%$, reaching the total amount to $\$ 63.9$ billion in 2017 (SIPRI, 2017; WEF, 2017).

Pakistan allocates and spends a huge amount on defence expenditures every year. The total outlay of budget 2017-2018 was estimated at Rs. 5,103.8 billion in which defence affairs and services expenditures were estimated to be Rs. 920.2 billion. The estimated increase in the defence budget is 7 percent for the financial year 2017-2018. Pakistan ranks at the $23^{\text {rd }}$ in world military spending and at $17^{\text {th }}$ in the list of countries holding weapons. The geo-strategic position of Pakistan and its least deterrence policy against neighbouring India have generally been the reason for stringent military financing. There is an immense interest in Pakistan's internal security in allocating funds to the military to curb terrorism and extremism in the country.

It has been discussed on various forums around the world that Pakistan and its neighbouring country India have engaged in a race in acquiring weapons for the last seven decades. This race has been caused due to various security, territorial disputes, economic 
and political factors. Therefore, this study investigates the impact of military spending on economic growth of Pakistan.

\section{Literature review}

Federal government budget spending on defence is one of the major concerns as this spending competes with the budget allocation in other social economic factors. The defence expenditure directly or indirectly affects all other sectors of the economy. Researchers have carried out several studies to verify the impact of military expenditure on the growth of the economy. Different studies show different effects of military spending on the country's growth. Some relevant literature studies show that military expenditure has a negative association with economic growth in a country, whereas most literature studies show a positive association between economic growth in a country and military expenditure. Review of some of the studies is given below.

Khilji and Mahmood (1997) studied the link between Pakistan's defence spending and its economic growth between 1972 and 1995. They used different single equation models for the estimation which are widely used in defence spending literature. The study used the causality test known as Granger Causality for the analysis and found bi-directional feedback between the variables. The study concluded from the estimated results that in Pakistan the relationship between the growth of an economy and its military spending is negative.

Sezgin (2000) used an Error Correction Mechanism (ECM) for studying the impact of Turkey and Greece military spending on their countries ' economic growth. They investigated Turkish and Greece defence burden growth related to the economic growth of both countries. The study found that Greece spent 5.74\% of the GDP on defence spending, while Turkey spent $4.42 \%$ of the GDP on defence spending. The study concluded that in both countries the effects of spending on the military demonstrate a positive association with short-term and long-term growth.

Baker (2007) used the global insight model for studying the impact of high military spending and expenditure of the Iraq war on the U.S economy. The projections showed that the annual increase in the military spending of the U.S is 1 percent of the GDP. The estimated results showed that the U.S increasing and higher military spending on the war in Iraq drain precious resources from the productive economy. The results further indicated that the higher spending on military leads to higher deficits in trade, slower economic growth, and less investment.

Hou (2009) used the panel and cross-sectional data for examining the nexus between Indian economic growth and its expenditure on defence. The study examined numerous facets of the efforts of the Indian defence. He used Richardson action-reaction model for 
studying Pakistan and Indian race for arms. The results indicated and supported that there exists continuing arms race between the two neighbouring countries. In addition, the estimated result indicated threat from Pakistan, political status, and income as the determinant of military expenditure of India. The study concluded that Indian's defence expenditures and growth of the economy have a negative relationship. Furthermore, D'Agostino et al. (2010) studied military spending impact on economic growth. They used Fader-Ram model for estimation modifying Solow and endogenous growth model using 28 countries data. The study concluded that the Fader-Ram model has so many weaknesses. They further indicated that both Solow and endogenous growth models show that spending on military and economic growth has a negative relationship.

Brauoveanu (2010) used techniques of quintile analysis, cluster analysis and Granger causality for analysing the association between Romania's military expenditure and growth expansion. The study examined the direction, presence, and intensity of the Romanian defence spending and their growth. He concluded that due to high proportional spending on equipment and operations in the country has negatively affected economic growth in the country.

Ali and Dimitraki (2014) used the regime-switching technique for studying the effects of Chinese military expenditure on growth expansion. They used a very interesting technique of Markov switching specification of two states using data from 1953 to 2010. They found that the growth of the economy and changes in military spending is dependent on the state. Furthermore, they found a negative link between military spending and growth in the midst of slower growth in the Chinese economy, while positive during faster economic growth. The study suggested that the increase in military spending may be harmful to growth during a slowdown growth.

Apanisile and Okunlola (2014) studied Nigerian defence spending and its effects on the growth in the economy using ARDL bound testing approach. They found a negative association between economic growth and military spending in the short term, while the association was positive in the long run. The study further found that capital and labour, which is the most important determinants of economic growth in a country have a significant and positive effect in the short and long run. They concluded and suggested that the government may reduce the expenditure on the military because of the reason that military expenditure contributing nothing to the Nigeria's economy in short run. The Nigerian government may concentrate on human capital development because human capital is the most important determinant of output.

Khalid et al. (2015) studied defence expenditure effect on U.S economic growth between 1970 and 2011, using Autoregressive Distributed Lag (ARDL) model. They investigated the externality effect on the economy of the United States of America. They focused on 
whether the military expenditure promotes technological progress, develop infrastructure and human capital or impeding a country's economic growth? They found and concluded that economic growth in the US is negatively linked to national defence expenditure.

Augier et al. (2015) examined defence spending effect on China's economic growth for the period 1952-2012. The study used data recently published on government expenditure, economic activity and defence spending using Feder-Ram and augmented Solow model for estimation. They found that the Feder-Ram model explained China's economic growth poorly. They concluded that the augmented Solow model shows that military expenditure and economic growth in China have positive links.

Dash et al. (2016) empirically studied the growth and defence expenditure link in BRIC bloc of economies for 1993-2014 using panel cointegration and causality for probing the link. The study mainly emphasized to know about the advantages of increasing military spending in that region as well as to know strategic and pre and post-war situation. The study concluded that military spending in the BRIC bloc economies has a positive impact on the growth in the economy.

\section{Research methods}

Feder (1983) presented a model for examining military spending and economic growth relationship, which was later extended by Biswas and Ram in 1986. Feder (1983) model was consisting of defence and civilian production function in a two-sector economy. Equations (1) and (2) shows both of these models as follows.

$$
\begin{aligned}
& D=D\left(L_{d} K_{d}\right) \\
& C=C\left(L_{c} K_{c} D\right)
\end{aligned}
$$

Where, the terms $L_{d}$ and $K_{d}$ shows the capital and labour shares to the defence sector and $L_{c}$ and $K_{c}$ shows civilian sector labour and capital shares. As indicated by Biswas and Ram (1986) in equation (2) "D" shows the externality effect to the civilian sector causing by the defence sector, which is the relative productivity factor differential for labour and capital in the two sectors mentioned above. The aggregate supply of labour and capital is shown in equations (3) and (4).

$$
\begin{aligned}
& L=L_{d} L_{c} \\
& K=K_{d} K_{c} \\
& Y=M+G
\end{aligned}
$$

By taking the total differential of the equation (5) and dividing it by $\boldsymbol{Y}$ (income), it gives the following equation (6).

$$
\frac{d Y}{Y}=\frac{d C}{d L} \frac{d L}{Y}+\frac{d G}{d K} \frac{d k}{Y}+\frac{d C}{d D} \frac{d D}{Y}
$$

Now by multiplying the first and last terms of equation (6) with $L / L_{L}$ and $M / M$ we will get the following equation (7). It indicates that how economic growth depends on weighted 
shares of labour growth as well as capital growth and defence in output. The partial derivatives, $\boldsymbol{F}$ are then found as estimated coefficients.

$$
\tilde{Y}=K_{l} L \frac{L}{Y}+F_{k} \frac{d k}{Y}+F_{d} D \frac{D}{Y}
$$

Hence, the empirical model designed for this study is a modified form of the equation (7) shows in equation (8) as follows.

$$
\ln Y=a_{1}+a_{2} \ln l+a_{3} \ln k+a_{4} \ln D+a_{5} \ln R+e
$$

Whereas $Y$ is the real GDP, $l$ shows Labour force, $k$ show capital stock, D shows spending on military, and $R$ represents real rate of interest and $\varepsilon$ indicates the error term. As at aggregate equilibrium in an economy total supply is equal to total demand. The modified shape of the model derived from equation (8) is therefore as follows.

$$
\ln Y(t)=a_{1}+a_{2} \ln G E(t)+a_{3} \ln M E(t)+a_{4} R(t)+\varepsilon(t)
$$

In equation (9) $\ln Y(t)$ shows the $\log$ of Gross Domestic Product, $\ln G E(t)$ indicates the $\log$ of non-military expenditures, $\ln M E(t)$ is the $\log$ of military expenditures, $R(t)$ represents the real interest rate in annual percentage form and $\varepsilon(t)$ is the error term. Whereas, $a_{1}$ is the intercept. And $a_{1}, a_{2}$ and $a_{3}$ are the respective coefficients in the model.

In order to examine the short- and long- term relationship between military expenditure and Pakistan's economic growth, the Auto Regressive Distributive Lag (ARDL) bound testing approach for co-integration is as follows:

$$
\begin{gathered}
\Delta G D P(t)=a_{0}+\sum_{i=1}^{p} a_{1} \Delta G D P(t-i)+\sum_{i=0}^{p} a_{2} \Delta G E(t-i)+\sum_{i=0}^{p} a_{3} \Delta M E(t-i) \\
+\sum_{i=0}^{p} a_{3} \Delta R(t-i)+\delta_{1} G D P(t-1)+\delta_{2} G E(t-1)+\delta_{3} M E(t-1)+\delta_{4} R(t-1)+\varepsilon(t)
\end{gathered}
$$

The ARDL bound test for cointegration, which is based on the F-statistics or WaldStatistics is suggested by Pesaran et al. (2001). The null hypothesis shows the absence of co-integration amongst the variables, while the alternate hypothesis shows the cointegration between the variables.

The acceptance or rejection of the null hypothesis is determined by the calculated value of the F-Statistics and the critical value of the bound test, using the given degrees of freedom (Narayan, 2005). If the estimated value of F-statistics is greater than the critical upper value, it means that the variables have a long-term relationship. However, if the calculated value of the F-statistic is lower than the lower limit, the variables do not have a long-term relationship. The long-term relationship between the variables is uncertain if the value of Fstatistics is between the lower and the upper limits (Hassan \& Kalim, 2012).

\section{Data}

This section provides details of the data, results, and discussion of the study. Section 4.1 shows details of the data. This section provides information about the variables, data, and 
data collection sources. After that, section 4.2 presents information about the analysis of the study. The details are as follows.

For the analysis, the current study used annual time series data for the period 1987 to 2016.The details of the data are given as follows in Table 1.

Table 1: Description of variables, time series annual data (1987-2016)

\begin{tabular}{|c|c|c|c|}
\hline Variables & Definition & Symbols & Sources \\
\hline $\begin{array}{l}\text { Gross domestic } \\
\text { product }\end{array}$ & $\begin{array}{l}\text { Gross domestic product in Pakistani } \\
\text { millions rupees }\end{array}$ & GDP & $\begin{array}{l}\text { World } \\
\text { Development } \\
\text { Indicators (2017) }\end{array}$ \\
\hline Military expenditures & $\begin{array}{l}\text { Military expenditure in Pakistani } \\
\text { millions rupees }\end{array}$ & ME & SIPRI (2017) \\
\hline $\begin{array}{l}\text { Non-Military } \\
\text { government } \\
\text { expenditures }\end{array}$ & $\begin{array}{l}\text { Non-Military government expenditures } \\
\text { in Pakistani millions rupees }\end{array}$ & GE & $\begin{array}{l}\text { Pakistan } \\
\text { Economic } \\
\text { Survey }\end{array}$ \\
\hline Real interest rate & Real interest rate in annual percentage & $\mathrm{R}$ & $\begin{array}{l}\text { State Bank of } \\
\text { Pakistan }\end{array}$ \\
\hline
\end{tabular}

\section{Results and discussion}

This study used Augmented Dickey Fuller (ADF) test for checking variables stationarity (Dickey and Fuller, 1979, 1981). The ADF test results are presented in Table 2 as follows:

Table 2: Results of the stationarity test

\begin{tabular}{lllcrrr}
\hline \multirow{2}{*}{ Variables } & \multirow{2}{*}{ Level } & \multirow{2}{*}{$\mathbf{Z}(\mathbf{t}) *$} & \multicolumn{3}{c}{ Critical values } & \multirow{2}{*}{-values } \\
\cline { 4 - 6 } & & -5.369 & $\mathbf{1 \%}$ & $\mathbf{5 \%}$ & $\mathbf{1 0 \%}$ & \\
\hline LGDP $_{\mathrm{t}}$ & At $1^{\text {st }}$ difference & -3.689 & -2.971 & -2.625 & 0.000 \\
LGE $_{\mathrm{t}}$ & At $1^{\text {st }}$ difference & -2.826 & -3.689 & -2.971 & -2.625 & 0.067 \\
LME $_{\mathrm{t}}$ & At $1^{\text {st }}$ difference & -4.997 & -2.650 & -1.653 & -1.609 & 0.000 \\
$\mathrm{R}_{\mathrm{t}}$ & At level & -3.151 & -3.711 & -2.981 & -2.629 & 0.035 \\
\hline
\end{tabular}

Table 2 indicates ADF-test results of the stationarity for the case of Pakistan. The test shows that the variable GDP is non-stationary which becomes stationary at I (1). The general government expenditure variable is also become stationary at the 1st difference at the 10 percent significance level, while military expenditure variable is also stationary at first difference while variable real rate of interest is stationary at level. As stationary results indicate that the variables for estimation are stationary at the level and at the first difference, the study can therefore confidently apply the ARDL model for this analysis (Khalid et al., 2015).

Table 3 shows the ARDL bound test for co-integration. The result that is estimated illustrates that the F-calculated value is 5.345. The relevant upper and lower bounds at the level of $10 \%$ are 2.676 and 3.586 respectively. The results indicate that the calculated value 
of the F-statistics is greater than the critical value of the upper bound, which suggests that co-integration exists.

Table 3: ARDL bound test results

\begin{tabular}{|c|c|c|c|c|c|c|}
\hline \multirow[t]{2}{*}{ F-statistics } & \multicolumn{2}{|c|}{ Critical value at $1 \%$} & \multicolumn{2}{|c|}{ Critical value at $5 \%$} & \multicolumn{2}{|c|}{ Critical value at $10 \%$} \\
\hline & $\mathrm{I}(0)$ & $\mathrm{I}(1)$ & $\mathrm{I}(0)$ & $\mathrm{I}(1)$ & $\mathrm{I}(0)$ & $\mathrm{I}(1)$ \\
\hline 5.345 & 4.614 & 5.966 & 3.272 & 4.306 & 2.676 & 3.586 \\
\hline $\mathrm{N}=30, \mathrm{~K}=3$ & & & & & & \\
\hline
\end{tabular}

Table 4 illustrates a parsimonious long-run ARDL bound test for cointegration. The estimated results show a long-term positive and significant relationship between GDP( $t$ ) and $\mathrm{GE}(\mathrm{t})$, which means that the increase in general government expenditure has a positive effect on the gross domestic product in the country. So an expansion of $1 \%$ in $\mathrm{GE}(\mathrm{t})$ prompts increment per capita GDP( $\mathrm{t})$ by $0.856 \%$. Similarly, $R(t)$ also having a negative relationship with GDP(t), and Khalid et al. (2015) found similar results. ME(t), on the other hand, has a positive relationship with GDP(t) in the long term and is statistically significant at 1 percent. The long-term positive and significant association of military expenditure with economic growth is not so ironic because the military runs a large number of schools, hospitals, etc. in Pakistan, which definitely have a positive effect on Pakistan's growth. The evaluated effects of the analysis are in accordance with (Sezgin, 2000; Alptekin and Levine, 2012; Augier et al., 2015; Mirza et al., 2015; Dash et al., 2016).

Similarly, Table 5 below shows the relationship of the variable in the short run. The estimated short-term coefficient illustrates that all the estimated variables are significant statistically at 1 percent level of significance. We found that military expenditure in the country has a negative effect on economic growth.

Table 4: Estimated long run coefficients

\begin{tabular}{|c|c|c|c|}
\hline \multicolumn{4}{|c|}{ Dependent variable: $\mathbf{L G D P}_{t}$} \\
\hline Variables & Coefficient & t-statistics & P-value \\
\hline Constant & $6.533^{*}$ & 7.228 & 0.000 \\
\hline $\mathrm{LGE}_{\mathrm{t}}$ & $0.856^{*}$ & 22.866 & 0.000 \\
\hline $\mathrm{LME}_{\mathrm{t}}$ & $0.443 *$ & 8.631 & 0.000 \\
\hline $\mathrm{R}_{\mathrm{t}}$ & $-0.022 * *$ & -2.283 & 0.045 \\
\hline \multicolumn{4}{|l|}{ Diagnostic test } \\
\hline \multicolumn{4}{|l|}{ Test statistics } \\
\hline $\begin{array}{l}\text { Jarque-Bera } \\
\text { (normality) }\end{array}$ & $1.1318[.568]$ & Not applicable & \\
\hline LM test (1) correlation & $3.085[.213]$ & $\mathrm{F}(2,8)=.5386[.603]$ & \\
\hline Heteroscedasticity & $2.802[.487]$ & $\mathrm{F}(15,10)=.8413[.630]$ & \\
\hline CUSUM test & Stable & Stable & \\
\hline CUSUMQ test & Stable & Stable & \\
\hline
\end{tabular}


Table 5: Short run results

\begin{tabular}{lccl}
\hline \multicolumn{2}{l}{ Dependent variable: DLGDP $_{\mathrm{t}}$} & & \\
\hline Variables & Coefficient & t-ratio & P-value \\
\hline DLGE $_{\mathrm{t}-1}$ & $-0.619^{*}$ & -3.659 & 0.004 \\
DLME $_{\mathrm{t}-1}$ & $-0.274^{* *}$ & -4.575 & 0.013 \\
DLME $_{\mathrm{t}-2}$ & $-0.163^{* *}$ & -2.985 & 0.013 \\
DR $_{\mathrm{t}-1}$ & -0.008 & -0.508 & 0.622 \\
DR $_{\mathrm{t}-2}$ & $0.032^{*}$ & 3.387 & 0.006 \\
ECT $_{\mathrm{t}-1}$ & $-0.864^{*}$ & -6.116 & 0.000 \\
\hline
\end{tabular}

$*, * *$ and $* * *$ represents coefficient significant at 1,5 and $10 \%$ percent, respectively.

We also examine the stability of coefficients in the short and long run, following Pesaran et al., (2001) which is cited in Bahmani-Oskooee (2001), the study applied the tests for checking the stability. The objective of stability test is to evaluate regression coefficient whether equation of the model is stable or not overtime. The test of stability is only apposite for annual time series data, particularly in the event that we are vague about a basic change in the data or uncertain about structural change in the data. So, for checking the stability of the coefficients CUSUM and CUSUMQ statistics are plotted against boundaries which are known as critical boundaries. According to Khalid et al., (2015) and Bahmani-Oskooee (2001), if the plotted statistics fall inside the critical boundaries, then we cannot reject the null hypothesis and conclude that the coefficients are stable.

Figures 1 and 2 show the plot of the two residuals CUSUM and CUSUMQ that fall within the 5 percent basic limits. As clear from given graphs, both the graphs of CUSUM and CUSUMQ are stable and confirms the long run stability of the coefficients.

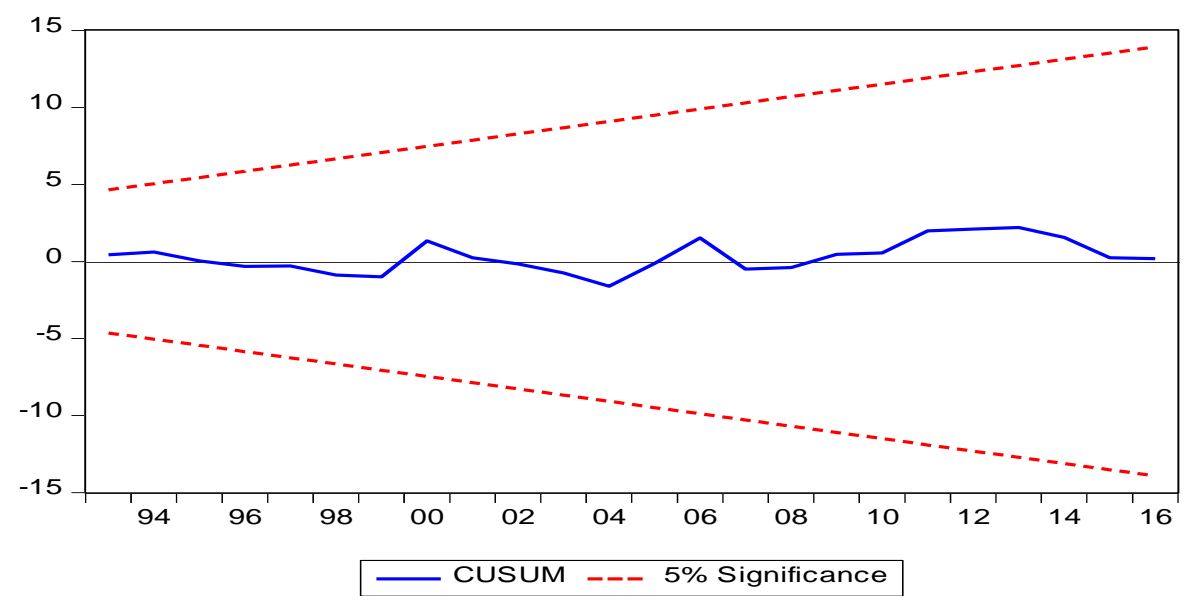

Figure 1: Cumulative sum of recursive residuals 


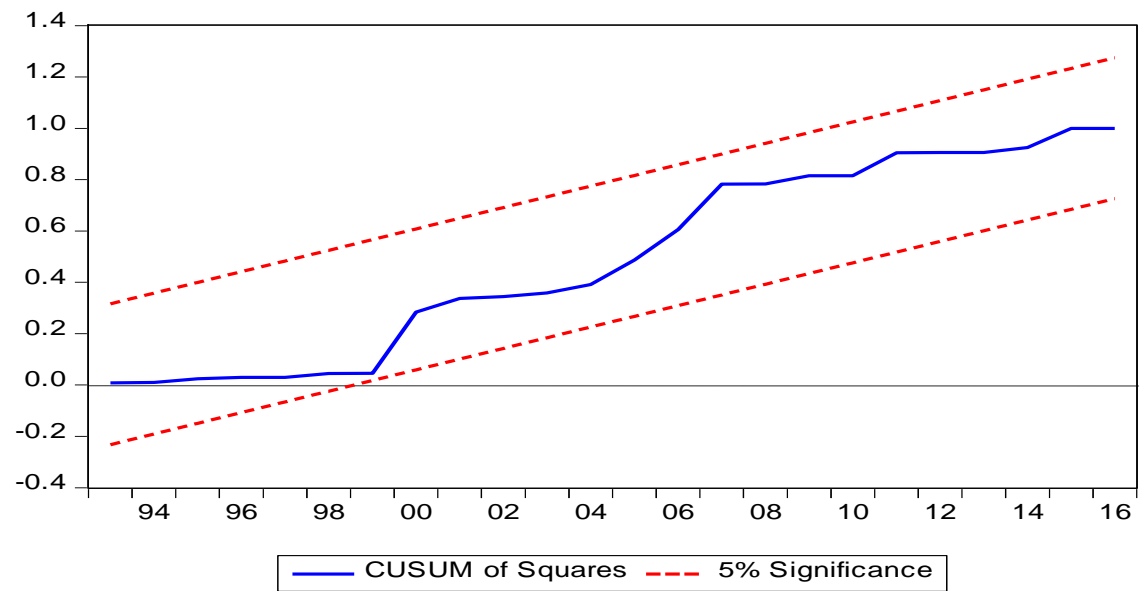

Figure 2: Cumulative sum of squares of recursive residuals

\section{Conclusion}

In this study, we investigated the short and long-term relationship between Pakistan's military spending and economic growth. Time series data from 1987 to 2016 were used for the analysis. Augmented Dickey Fuller test and Autoregressive Distributed Lag (ARDL) bounds testing approach used for data analysis. The findings indicate that military expenditure has a positive impact on Pakistan's economic growth in the long-run, however it has negative effect on economic growth in the short-run. This study concluded that military spending is an important positive factor in Pakistan's economic growth in the longrun.

\section{References}

Alptekin, A., \& Levine, P. (2012). Military expenditure and economic growth: A metaanalysis. European Journal of Political Economy, 28, 636-650.

Ali, F. M., \& Dimitraki, O. (2014). Military spending and economic growth in China: A regime-switching analysis. Applied Economics, 1-39.

Apansile, O. T., \& Okunlola, O. C. (2014). An empirical analysis of effects of military spending on economic growth in Nigeria: A bound testing approach to co-integration 1989-2013. Journal of Public Administration, Finance and La, 6, 117-130.

Augier, M., Mcnab, R., Guo, J., \& Karber, P. (2015). Defence spending and economic growth: Evidence from China. Journal of Defence and Peace Economics, 1-26.

Bahmani-Oskooee, M. (2001). Real and nominal effective exchange rates of Middle Eastern countries and their trade performance. Applied Economics, 33, 103-111.

Baker, D. (2007). The economic impact of the Iraq war and higher military spending. Centre for Economic and Policy Research 1611 Connecticut Avenue, NW, Suite 400 Washington, D.C. 20009. 
Benoit, E. (1973). Defence and economic growth in developing countries. Boston MA: Health. Lexington Books.

Biswas, R., \& Ram, R. (1986). Military expenditure and economic growth in LDC: An augmented model and further evidence. Economic Development and Cultural Change, 34(2), 361-37.

Brauoveanu, L. O. (2010). The impact of defence expenditure on economic growth. Romanian journal of economic forecasting, 13(4), 148-167 .

D’Agostino, G., Dunne, J.P., \& Pieroni, L. (2010) Assessing the effects of military expenditures on economic

growth. Forthcoming chapter in the Oxford Handbook of the Economics of Peace and Conflict, edited by Stegios Skaperdas and Michelle Garfinkel. Oxford: Oxford University Press.

Dash, D. P., Bal, D. P., \& Sahoo, M. (2016). Nexus between defence expenditure and economic growth in BRIC economies: An empirical investigation. Theoretical and Applied Economics, 1, 89-102.

Dickey, D., \& Fuller, W. (1979). Distribution of the estimators for autoregressive time series with a unit root. Journal of the American Statistical Association, 74(366), 427-431.

Dickey, D., \& Fuller, W. (1981). Likelihood ratio statistics for autoregressive time series with a unit root. Econometrica, 49(4), 1057-1072.

Feder, G. (1983). On exports and economic growth. Journal of Development, 12(1-2), 5973.

Fiani, R., Annez, P., \& Taylor, L. (1984). Defence spending, economic structure, and growth: Evidence among countries and over time. Economic Development and Cultural Change, 32, 487-98.

Hassan, M. S., \& R. Kalim (2012). The triangular causality among education, health and economic growth: a time series analysis of Pakistan. World Applied Sciences Journal, 18(2) 196-207.

Hou, N. (2009). Arms race, military expenditure and economic growth in India. Department of Economics Business School the University of Birmingham.

Khalid, M. A., \& Abdul Razaq, M. A. (2015). The impact of military spending on economic growth: Evidence from the US economy. Research Journal of Finance and Accounting, 6(7), 183-190.

Khilji, N, M., \& Mahmood, A. (1997). Military expenditure and economic growth in Pakistan. Pakistan Development Review, 36(4), 791-808.

Mirza, M. N., Jaspal, Z., \& Malik, A. I. (2015). Military spending and economic growth in Pakistan. Margalla Papers, 151-184. 
Narayan, P. (2005). The saving and investment nexus for China: Evidence from cointegration tests. Applied Economics, 37(17), 1979-1990.

Pesaran, M. H., Shin, Y., \& Smith, R. J. (2001). Bounds testing approaches to the analysis of level relationship. Journal of Applied Econometrics, 16(3), 289-326.

Sezgin, S. (2000). Defence expenditure and economic growth in turkey and Greece: A cointegration analysis. MuğlaÜniversitesi SBE Dergisi Güz 2000 Cilt: 1Sayı: 1, 1-12.

SIPRI Yearbook 2017: Armaments, disarmament and international security. Oxford: Oxford University Press.

World Economic Forum (2017). https://www.weforum.org/agenda/2018/05/india-worldsbiggest-defence-military-spender/ 